\title{
Applying the Paschalidis Tri-Anthropo-Type Model in the Lower Secondary School: A Case Study
}

\author{
George D. Paschalidis ${ }^{1}$, Kalliopi Chiou ${ }^{2}$, Pinelopi Papathanasiou ${ }^{3}$, Polyxeni Karaviti ${ }^{4}$ \\ ${ }^{1}$ Researcher \\ ${ }^{2}$ Coordinator of Psychological Rehabilitation Centre \\ ${ }^{3}$ Secondary-School Teacher \\ ${ }^{4}$ Secondary School Teacher, Theatre/Drama Educator \\ Greece
}

\begin{abstract}
This research paper examines the application of the Paschalidis Tri-Anthropo-Type Model in lower secondary education. The Model was used with a class of First Year students of a lower secondary school in Northern Greece, in the context of the newly introduced subject "School Life and Social Life". The main aim of the application was to assist the students' transition from primary to secondary school and their adaptation to their new educational context. To conduct the study, seminar training material of the Tri-Anthropo-Type Paschalidis Model, questionnaires, comprehension exercises and experiential activities were employed. Questionnaires, structured interviews and qualitative observations were used for data collection. The results showed a smoother adaptation of students to the new environment after the intervention, greater awareness of self and others, improved selfconfidence, reduced verbal aggressive behaviours, a growing climate of trust and cooperation, as well as improvement of certain pupils' behavioural problems. Finally, the teacher recorded increased job satisfaction and reduced anxiety.
\end{abstract}

\section{Introduction}

In the beginning of the school year 2013-2014, the teacher taught the subject "School life and Social life" in a First Year class for an hour per week. This newly introduced subject focuses on students' holistic development as individuals and as social beings. She came upon the following issues: a) a climate of inadequate communication and interaction between pupils b) anxiety and tension due to incomplete understanding of the new educational framework and c) teasing, verbal confrontations and a lack of coherence in the group of students.

It is known that the transition from childhood to adolescence is accompanied by a number of changes concerning their emotions, development and socialization: children experience a loss of their childhood and of total dependence on their parents, find themselves having to deal with gradual adaptation to greater responsibilities and emotional autonomy [1] [2]. At the same time, the transition from primary to secondary education is a source of stress and worry for students about whether and how they can cope with the increased school demands [3]. Research shows that difficulties in school transition can either lead to an unpleasant school experience for everyone involved in the educational process or to school dropout.

The above difficulties worried the teacher and reduced enjoyment from her work, so she decided to help her students cope with these challenges through enhancing their self-awareness and self-esteem as well as their hetero-awareness (awareness of the "other"). The Paschalidis Tri-Anthropo-Type Model, which she came across in the literature, seemed to her an appropriate approach [4].

According to the Model, every person belongs to only one of three distinct personality Types: A, B or $\mathrm{C}$, differentiated mainly by brain function and plasticity. The three personality Types are classified according to certain physiological, neuroanatomical and neurochemical characteristics as well as personality traits [5], which are genetically specified and inherited by one's biological parents.

The Model introduces what it defines as the "dominant gene" factor, which also plays significant role in Type-specific characteristics. Despite the fact that there are only three personality Types, and therefore three distinct Types of idiosyncrasy (Type A characterized by action, Type B characterized by nervousness and Type $\mathrm{C}$ characterized by order, dogmatic), there are six sub-types depending on whether one has inherited their personality Type from their mother or their father. In the Model this is known as "dominant gene".

The dominant gene defines the way each person handles and manages their life and relations. People who have inherited their dominant gene from their father, they exhibit a male attitude as far as their behaviour, actions and reactions are concerned, no matter the personality Type they belong to. They tend to be more tense and abrupt, extrovert and lacking diplomacy skills. People who have inherited their dominant gene from their mother, they exhibit a 
female attitude as far as their behaviour, actions and reactions are concerned, no matter the personality Type they belong to. They tend to express themselves in a softer and gentler manner, are analytical, introvert and accepting. When the dominant gene coincides with the genetic sex (i.e. male dominant gene and male sex) the personality traits are in greater harmony with the traits of the sex $[5]$.

Each Type has a specific reaction to stress. When Type A individuals are under pressure, they become tense. They experience a specific kind of stress, defined by G. D. Paschalidis as "stress of panic of action". This condition either leads them to quick, careless, nonproductive action or to a reaction of giving up and inactivity. When Type $\mathrm{B}$ individuals are under pressure, they become watchful and cautious in order to avoid making mistakes. They experience a specific kind of stress, defined by G. D. Paschalidis as "stress of anxiety". This condition leads them to unproductive repeated cycles of thinking, planning and checking, so that they become unable to make neither any decision nor take any action. When Type $\mathrm{C}$ individuals are under pressure, they become persistent. They experience a specific kind of stress, defined by G. D. Paschalidis as "stress of persistence of performance/stubbornness of execution" which leads them to persist obsessively in what they consider as the only "right" way of acting, which happens to be the most difficult one, unable to see alternatives. As a result, they cannot proceed towards fulfillment of their goals [6].

As far as education is concerned, there are three distinct learning profiles, as well as three teaching styles [4]. Type A students are visual, process information quickly and focus on facts and images. Type B students are auditory, process information slowly and focus on theories and written texts. Type C students are both visual and auditory, pay excessive attention to details whilst process information and focus on ideas, images and written texts.

According to the Model, students have certain Type-specific personality traits. When they do not have to face stressful stimuli and are relaxed, they exhibit their positive qualities. Type A students, for example, are spontaneous, self-confident, cooperative, communicative, decisive, natural leaders and easily pleased. Type B students are friendly, affectionate, polite, careful, considerate, patient and Type C students are passionate, committed, focused, giving, hard working.

However, when Type A students are exposed to stressful stimuli, their entorhinal cortex gets overactive and certain problematic aspects of their personality prevail. They panic, get restless, unpredictable, inpatient, clumsy, quick-tempered and easily give up. When Type B students are exposed to stress their amygdala gland gets overactive and they worry, procrastinate, get anxious, indecisive, insecure reserved and withdraw, hesitate. Finally, when Type $\mathrm{C}$ students are exposed to stress, their hippocampus gets overactive and they become competitive, stubborn, obsessed, persistent, suspicious, unforgiving, they fear rejection [6].

In the classroom, and when under stress, Type A students are hyperactive and get easily bored, Type B students are chatterers and doubtful and Type C students get aggressive and disobedient. The aim of the intervention was to facilitate the students' adaptation in the new school environment. In particular: a) to establish a climate of communication and cooperation among students and facilitate their bonding with their classmates and the formation of new friendships, b) to soothe students' anxiety and tension and to facilitate understanding of the new educational framework, c) to reduce verbal conflicts and teasing and d) to improve certain students' dysfunctional behaviours.

All the above could be achieved by developing self-awareness and hetero-awareness, both contributing to a greater sense of confidence and safety. For this purpose, action research was considered as the most appropriate research methodology, since it constitutes an educational research process involving the teacher as researcher and aiming at bringing positive change both in themselves and their pupils.

\section{The research}

The intervention took place in the context of the subject "School life and Social life" in the form of a project entitled "Getting to know ourselves and others by applying the knowledge of human Personality Types", during the school year 20132014, an hour per week. The teacher was the main person responsible for the intervention. She was assisted by G.D. Paschalidis, researcher and founder of the Model, who offered her regular feedback concerning her practice and research, in the role of an external collaborator. A certified psychologist contributed to the data processing and statistical analysis. A fellow colleague acted as a critical friend.

\subsection{The identity of the class}

The class consisted of 16 First Year students (10 girls and 6 boys) aged between 12 and 13, of a secondary school in Pieria region, Macedonia, Greece. Apart from the difficulties mentioned above, $25 \%$ of the class displayed specific behavioural and 
emotional problems. In particular: Schoolgirl 1 showed lack of certain social skills and of interest in school life and school work. She did not trust others and at times was aggressive. Schoolgirl 2 had difficulties in expressing herself, was reserved and hesitated to participate in class. Schoolgirl 3 used to get easily angry with her teacher and her classmates, to seek perfection and to get stressed when she didn't achieve excellent marks. Schoolboy 1 could not remain still and focus his attention. $\mathrm{He}$ was displaying symptoms of attention deficiency, but without an official diagnosis.

\subsection{Methodology, materials, activities}

Observations, Tri-Anthropo-Type Paschalidis questionnaires, structured interviews with the students, the teacher's journal and the students' portfolios and working sheets were the research tools used.

Triangulation was used to ensure intersubjectivity of the findings. In particular, three different ways of data collection were used (observation, questionnaire, structured interview). Data was collected from two different sources (the teacher and the students).

The research process consisted of two main steps. First step: The teacher attended a training course on the application of the Paschalidis Tri-Anthropo-Type Model in secondary school education, taught by G.D. Paschalidis, where she was provided with the necessary guidelines and materials for the intervention.

Second step: The teacher introduced the students to the Model through three sections of activities entitled: "Getting to know the Paschalidis TriAnthropo-Type Model", "Getting to know my personality Type and the personality Types of my schoolmates", and "Applying the Model in my everyday life".

In the first section of activities, the students became familiar with the Model. Audiovisual material, relevant articles, fairytale-Type stories, matching cards of emotional states and personality traits, biographies of historical figures, songs related to the Paschalidis personality Types, excerpts from Plato's "The Republic" and closed-questionsworksheets were used.

In the second section of activities, the TriAnthropo-Type Paschalidis Questionnaire for teenagers, mimicry, structured interviews, worksheets investigating interests and motives, as well as open-ended questions were used, in order for students to recognize their personality Type.

The third section of activities included: presentations of students' projects on the personality
Types, role play, closed-question worksheets including suggestions on the implementation of the Model for the development of meaningful interpersonal relationships. Personal experiences of the students were discussed, aiming at self-awareness and hetero-awareness, as well as suggestions for the effective management of stress both at school and at home, depending on the personality Type.

A questionnaire consisting of 21 statements, 10 concerning confidence - self-esteem and 11 the evaluation of the class atmosphere was filled in by the students before and after the intervention. This questionnaire was a short version of a bigger questionnaire used by the school in order to help students evaluate the school environment. Structured interviews with each student were contacted, based on the axes: "Knowing myself", "Knowing others" and "Changing myself."

\section{Results}

The structured interviews, as well as the questionnaires used, showed that $56,25 \%$ of the students belonged to Type B, 25\% to Type A and $18,75 \%$ to Type $\mathrm{C}$ (Figure 1). The teacher was identified as belonging to Type B.

Through the worksheets that were used in the second section of activities (aimed at investigating students' interests and motives), students realized that their motivation and preferences about their future profession, as well as their hobbies and athletic activities, were directly correlated to the personality Type they belonged to.

Qualitative analysis of the structured interviews showed positive change concerning the following variables: "Knowing myself", "Knowing others" and "Changing myself" (Table 1). As far as the first variable is concerned, students stated before the intervention: "I don't like my getting worried" (Type B), "My friends call me stubborn" (Type C), "Sometimes I find myself being outraged without any obvious reason" (Type A), "I often feel that my friends don't really want me as their friend" (Type C) etc. After the intervention, students stated: "I've learned who I am and feel better about myself now" (Type B), "I can finally understand why I worry" (Type B), "I now know that my friends like me and

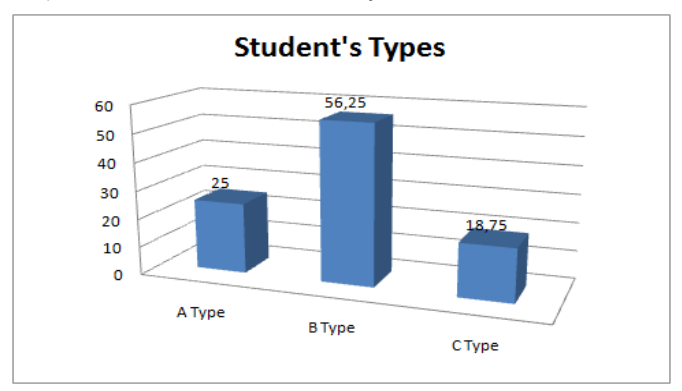

Figure 1. Students’ personality Types 
that it was my personality Type that "made" me think wrongly about them" (Type C). As far as the second variable is concerned, before the intervention they said: "My dad is tense all the time" (Type A father), "I can't understand why my friend is so shy" (Type B friend), and after the intervention: "I now know what annoys me in my schoolmates' behaviour and why" (Type B), "As I was learning about the personality Types, I could recognize many elements of my family members' behaviour" (Type A). As far as the third variable is concerned, before the intervention students said: "I don't want to feel fear anymore" (Type B), "I want to learn how to study quicker" (Type B), "I wish I could be less obsessive with my goals" (Type C) and after the intervention: "I don't worry about failing anymore" (Type C), "This project has helped me to be happier" (Type B), "Thanks to this project I feel more relaxed about my goals" (Type C).

Thematic analysis of the interviews before the intervention showed the following (Table 2): 9 out of $16(56,25 \%)$ pupils talked about their worrying and anxiety about adapting to secondary school and 8 out of $16(50 \%)$ found it hard to give more than two positive and two negative traits of their personality. Nine (9) out of $16(56,25 \%)$ said that they face difficulties with their schoolmates' behaviour; amongst them, 3 out of $16(18,75 \%)$ talked about behaviours that made them angry or upset, 4 out of $16(25 \%)$ about behaviours that made them angry and anxious and 2 out of $16(12,50 \%)$ spoke about behaviours that bothered them and led them argue with their classmates.

Table 1. Changes in students' self and hetero awareness

\begin{tabular}{|c|c|c|}
\hline & $\begin{array}{l}\text { Before the } \\
\text { intervention }\end{array}$ & $\begin{array}{l}\text { After the } \\
\text { intervention }\end{array}$ \\
\hline $\begin{array}{c}\text { Self } \\
\text { awareness }\end{array}$ & $\begin{array}{lr}\text { "I don't like } \\
\text { my } & \text { getting } \\
\text { worried" } & \text {-Type } \\
\text { B, } & \\
\text { call } & \text { friends } \\
\text { call me } & \text { my } \\
\text { stubborn" } & \text {-Type } \\
\text { C, "Sometimes } \\
\text { I hurt others } \\
\text { when I speak } \\
\text { without realizing } \\
\text { it" - Type A }\end{array}$ & $\begin{array}{l}\text { "I can finally } \\
\text { understand why } \\
\text { I worry" - Type } \\
\text { B, "I can now } \\
\text { "I cand that } \\
\text { understand } \\
\text { I have to stop } \\
\text { insisting } \\
\text { sometimes" } \\
\text { Type C, } \\
\text { "I am now } \\
\text { more careful } \\
\text { when I speak" - } \\
\text { Type A }\end{array}$ \\
\hline $\begin{array}{r}\text { Hetero } \\
\text { awareness }\end{array}$ & $\begin{array}{l}\text { "My dad is } \\
\text { tense all the } \\
\text { time" -Type A } \\
\text { with a Type A } \\
\text { father, }\end{array}$ & $\begin{array}{l}\text { "As I was } \\
\text { learning about } \\
\text { the personality } \\
\text { Types, I could } \\
\text { recognize many }\end{array}$ \\
\hline
\end{tabular}

\begin{tabular}{|c|c|c|}
\hline & $\begin{array}{l}\text { "I can't } \\
\text { understand why } \\
\text { my friend is so } \\
\text { shy" -Type C } \\
\text { with a Type B } \\
\text { friend, } \\
\text { "I cannot } \\
\text { understand my } \\
\text { friend; he cannot } \\
\text { make up his } \\
\text { mind!" -Type A } \\
\text { for a Type B } \\
\text { friend "Sometimes } \\
\text { my friends' } \\
\text { words hurt me" } \\
\text {-Type B with a } \\
\text { Type A friend }\end{array}$ & $\begin{array}{l}\text { elements of my } \\
\text { family members' } \\
\text { behaviour" } \\
\text { Type A, } \\
\text { "I can now } \\
\text { understand why } \\
\text { my friend is so } \\
\text { shy and now I } \\
\text { can help him" - } \\
\text { Type C with a } \\
\text { Type B friend } \\
\text { "I see why } \\
\text { he is so } \\
\text { indecisive! I do } \\
\text { not get upset so } \\
\text { much anymore" } \\
\text {-Type A for a } \\
\text { Type B friend } \\
\text { "I know now } \\
\text { that he does not } \\
\text { hurt me on } \\
\text { purpose. I do } \\
\text { not pay so much } \\
\text { attention to it } \\
\text { anymore." }- \\
\text { Type B with a } \\
\text { Type A friend }\end{array}$ \\
\hline $\begin{array}{c}\text { Self } \\
\text { development }\end{array}$ & $\begin{array}{l}\text { "I hate } \\
\text { failure!"-Type C } \\
\text { "I find it hard } \\
\text { to be happy } \\
\text { here; it is so } \\
\text { boring"- Type C } \\
\text { "I have lost } \\
\text { my old friends. } \\
\text { How am I going } \\
\text { to make new } \\
\text { ones now?" - } \\
\text { Type B, "I want to } \\
\text { learn how to } \\
\text { study quicker" - } \\
\text { Type B }\end{array}$ & $\begin{array}{l}\text { "I don't worry } \\
\text { about failing } \\
\text { anymore" -Type } \\
\text { C, "This project } \\
\text { "This helped me } \\
\text { has be happier" - } \\
\text { to by } \\
\text { Type C } \\
\text { "I am not } \\
\text { anxious } \\
\text { anymore; I've } \\
\text { made new } \\
\text { friends" -Type B } \\
\text { "I feel more } \\
\text { confident now, I } \\
\text { am not anxious } \\
\text { about reading } \\
\text { anymore" -Type } \\
\text { B }\end{array}$ \\
\hline
\end{tabular}

After the intervention, 14 out of $16(87,5 \%)$ recognized more than eight traits of their personality and managed to explain their own behaviour, 12 out of $16(75 \%)$ said that they could understand better the behaviour of their friends and family, 12 out of $16(75 \%)$ said that they were more courageous, happier and less stressful about school and 6 out of $16(56,25 \%)$ felt that they had improved elements of their behaviour, which caused them trouble with others. 
Table 2. Changes in students' self and hetero awareness (thematic analysis' results)

\begin{tabular}{|l|l|}
\hline $\begin{array}{l}\text { Before the } \\
\text { intervention }\end{array}$ & After the intervention \\
\hline $\begin{array}{l}\mathbf{5 6 , 2 5 \%} \text { talked about } \\
\text { their worrying and anxiety } \\
\text { about adapting to } \\
\text { secondary school. }\end{array}$ & $\begin{array}{l}\mathbf{7 5 \%} \text { said that they } \\
\text { were now more relaxed and } \\
\text { happier about school. }\end{array}$ \\
$\begin{array}{l}\mathbf{5 0 \%} \text { found it hard to } \\
\text { give more than two } \\
\text { positive and two negative } \\
\text { traits of their personality. }\end{array}$ & $\begin{array}{l}\mathbf{8 7 , 5 \%} \text { recognized more } \\
\text { personality and managed to } \\
\text { explain their own } \\
\text { behaviour. }\end{array}$ \\
\hline $\begin{array}{l}\mathbf{5 6 , 2 5 \%} \text { said that they } \\
\text { face difficulties with their } \\
\text { schoolmates' behaviour. }\end{array}$ & $\begin{array}{l}\mathbf{7 5 \%} \text { said that they } \\
\text { could now understand } \\
\text { better the behaviour of } \\
\text { their friends and family. }\end{array}$ \\
\hline $\begin{array}{l}\mathbf{5 6 , 2 5 \% ~ r e c o g n i z e d ~} \\
\text { behaviours that caused } \\
\text { them anger (18,75\%), } \\
\text { anxiety (25\%) or led them } \\
\text { to argue with their } \\
\text { classmates (12,5\%). }\end{array}$ & $\begin{array}{l}\mathbf{5 6 , 2 5 \%} \text { felt that they } \\
\text { their behaviour, which had } \\
\text { caused them trouble with } \\
\text { others previously. }\end{array}$ \\
\hline
\end{tabular}

Statistical analysis of the questionnaires before and after the intervention, showed statistically significant difference $\mathrm{t}(15)=-4,858, \mathrm{p}=.00$ in selfconfidence and self-esteem. It also showed statistically significant difference $t(15)=-4,789$, $\mathrm{p}=.00$ in the class atmosphere, which students thought of as more peaceful after the intervention.

As far as the class atmosphere is concerned, before the intervention there was limited interaction and inadequate interpersonal relations amongst students, whereas after the intervention the cohesion of the class improved. The teacher notes: "The class atmosphere started to change gradually. I was pleasantly surprised by the fact that students communicated more efficiently and a feeling of togetherness, trust and solidarity was established. Students began to bond with each other."

Restlessness and tension in the class started to subside, since according to the teacher "Students became more and more interested in the Model and they were focused on their learning about it. They researched the subject further on their own initiative. They felt more relaxed, started to express their opinions and feelings more openly, to get more joyful and develop their sense of humor. All students became more relaxed, which had a positive impact in the class atmosphere. Type A students became less hyperactive, Type B students stopped talking all the time and Type $C$ students became more receptive."

As far as problematic behaviours are concerned, the teacher noticed that verbal abuse among students in class became less. Their working on the Model helped them improve their self-knowledge as well as their knowledge of the other. This led them to accept each other more easily and to relate better.

As far as students with behavioural issues are concerned, positive changes were noticed. Schoolgirl 1, identified as belonging to Type $\mathrm{C}$, started to form friendships within the class, to cooperate with her classmates and to participate in the educational processes. Schoolgirl 2, identified as belonging to Type B, became more extrovert and less shy. Schoolgirl 3, identified as belonging to Type C, stopped to get easily angry with her teacher and her classmates, to seek perfection and get stressed when she didn't achieve excellent marks. Schoolboy 1, identified as belonging to Type $\mathrm{B}$, began to be calmer and could now remain still and focus his attention for longer than before the intervention.

The teacher noticed positive change concerning her anxiety management, as well as her relating with the pupils. "I could now understand each student's personality peculiarities and found appropriate ways to approach them. I stopped getting angry with them and thus our communication improved. My students were transformed from a source of anxiety into a source of inspiration and joy for me. Knowing myself better through the Model, I relied on my strengths and stopped being influenced by my weaknesses».

\section{Discussion}

The findings indicated that the application of the Model helped students to understand themselves and their classmates better and to explain their own behaviour, as well as the behaviour of others, more easily. They realized that certain problematic behaviours derive from characteristics of one's personality Type and as soon as they are identified they can be limited. These will allow individual development and flourishing of one's uniqueness.

Students' self-esteem and confidence, acceptance, friendship and collegiality were boosted. Aggressive behaviours decreased and adaptation to the new school environment was alleviated. The application of the Tri-Anthropo-Type Paschalidis Model assisted the teacher in managing her work-related stress and drawing more pleasure from her work.

The positive impact of the application of the Paschalidis Model in lower secondary education in the specific school constitutes strong evidence that application in any similar environment can have similar effect. Previous research on the application of the Model in preschool education supports this claim [7].

As far as quantitative and qualitative data are concerned, a larger sample of students could supply a more comprehensive and reliable picture of the effect of the intervention. 
This action research study constituted an experience of positive change for both the students and the teacher-researcher. Therefore, we feel we can recommend a generalized application of the TriAnthropo-Type Paschalidis Model in education. This would reduce teachers' work related stress and increase their job satisfaction. It would also promote deeper understanding of self and the other and would therefore assist students' transition in new school environments, and foster acceptance, tolerance and cooperation.

\section{References}

[1] B.H. Connoly, "Transition from childhood to adulthood", Psysical \& Occupational Therapy in Pediatrics, Informa, UK, 2002, pp. 1-2.

[2] R.M. Lerner, and N.L. Galambos, "Adolescent development Challenges and Opportunities for Research Programs and Policies", Annual Review of Psychology, Annual Reviews, USA, 1998, pp. 313-414.

[3] S.K. Waters, L. Lester, and D. Cross, "Transition to secondary school: expectation versus experience", Australian Journal of Education, Sage, Australia, 2014, pp. 153-166.

[4] A. Stathopoulou, and G. Paschalidis, "The model of the three human personality types: a unique tool for the understanding of the individual differences in the teachinglearning process", Proceedings of 5th International Conference of Education, Research and Innovation, Madrid, 2012, pp. 2050-2059.

[5] A. Stathopoulou, and G. Paschalidis, "Genetically determined differences of the three structures of limbic brain system determine three distinctive and unique personality types: a special key for understanding connection between brain function and its plasticity with health prevention", Proceedings of 18th International Neuroscience and Biological Psychiatry Conference, New Orlean, 2012, pp. 22-23.

[6] G. D. Paschalidis, "The Paschalidis Tri-Anthropo-Type Model in Education: Three Learning Profiles, Three Teaching Styles", Literacy Information and Computer Education Journal, Infonomics Society, UK, 2014, pp. 1511-1517.

[7] G. D. Paschalidis, D. Avlogiari, P. Karaviti, and K. Chiou, "Applying the Paschalidis Tri-Anthropo-Type Model in the Kindergarten: A Case Study", International Journal for Cross-Disciplinary Subjects in Education, Infonomics Society, UK, 2015, pp 2106-2110. 